\title{
Evaluation of the profile of drug therapy administered through enteral feeding tube in a general hospital in Rio de Janeiro
}

\author{
Mario Jorge Sobreira da Silva ${ }^{1 *}$, Carlos Eduardo Meireles Cava², Patrícia Kaiser Pedroso², \\ Débora Omena Futuro ${ }^{3}$
}

\begin{abstract}
${ }^{1}$ Pharmacy Service, Hospital of the Servers of the State and Pharmacy Course, Health Sciences School, UNIGRANRIO, ${ }^{2}$ Hospital Pharmacy, Faculty of Pharmacy, Federal Fluminense University, ${ }^{3}$ Pharmaceutical Technology Department, Faculty of Pharmacy, Federal Fluminense University
\end{abstract}

\begin{abstract}
Enteral nutrition (EN) is the method of choice for patients that cannot adequately receive oral feeding despite good gastrointestinal tract condition. Enteral diets may be administered through tube or ostomy placed in the stomach, duodenum or jejunum. The administration of drugs via enteral feeding tube (EFT) is a common practice in hospitals due to patient clinical status, and requires special attention from professionals involved in this process. This study entailed an analysis of the profile of drug therapy through EFT based on evaluation of medical prescriptions of the Medical Clinic of the Hospital dos Servidores do Estado (HSE) of Rio de Janeiro sent to the Pharmacy Service between January and June 2007, according to standard protocols in place. Prescription of drugs via EFT outside recommended guidelines was observed, besides potential drug-nutrient incompatibilities associated with this practice. These results point to the need for improvement of enteral route access and the adoption of measures to promote safe and effective use of drugs and nutritional therapy.
\end{abstract}

Uniterms: Enteral nutrition. Drugs/prescriptions. Hospital pharmacy. Pharmaceutical care.

\begin{abstract}
A nutrição enteral (NE) é o método de escolha para alimentar pacientes que não podem receber alimentação por via oral de forma adequada, mas que estejam com a função gastrointestinal satisfatória para a absorção dos nutrientes. As dietas enterais podem ser administradas através de cateteres ou ostomias, posicionados no estômago, duodeno ou jejuno. A administração de medicamentos através de cateter de nutrição enteral (CNE) é uma prática muito comum no ambiente hospitalar, devido ao estado clínico do paciente, necessitando atenção especial dos profissionais envolvidos neste processo. $\mathrm{O}$ estudo constituiu uma análise do perfil da terapia medicamentosa através de CNE por meio de uma avaliação das prescrições médicas da Clínica Médica do Hospital dos Servidores do Estado (HSE) do Rio de Janeiro encaminhadas ao Serviço de Farmácia, de janeiro a junho de 2007, tendo como padrão protocolos existentes. Foi observada a prescrição de medicamentos através do CNE fora das recomendações contidas nas referências, além de possíveis incompatibilidades fármaco-nutriente associadas a esta prática. Os resultados demonstraram a necessidade de melhoria na utilização dessa via e adoção de medidas a fim de promover um uso seguro e eficaz de medicamentos e da terapia nutricional.
\end{abstract}

Unitermos: Nutrição enteral. Medicamentos/prescrição. Farmácia hospitalar. Assistência farmacêutica.

\section{INTRODUCTION}

Enteral nutrition (EN) is indicated for patients who, for some reason, are unable to ingest food orally despite their digestive system functioning both anatomically

*Correspondence: M. Sobreira. Av. Maracanã, 450 - Apto. 105 - Maracanã, 20271-111 - Rio de Janeiro - RJ. E-mail: mjsobreira@yahoo.com.br and physiologically (SENPE, 1998). The access routes to the digestive tube for insertion of the enteral feeding tube (EFT) may vary according to gastrointestinal tract pathology and general patient clinical status. The most used access approaches are nasoenteral route, gastrostomy and jejunostomy. EN may be administered through EFT by intermittent or continuous forms (Waitzberg et al., 2000).

High number of patient candidates to receive EN 
need treatment with one or more drugs that may also be administered through the EFT (Beckwith et al., 2004). The use of an inappropriate method of drug administration via this route can lead to failures both to medication and nutritional therapy (Gámez Lechuga et al., 1998). Problems related to administration of drugs via EFT may result from a series of incompatibilities such as physical, pharmaceutical, physiological, pharmacological and pharmacokinetic (Izco et al., 2001).

Physical incompatibility happpens when physical change occur after mixing the EN and the drug. This may lead to formation of precipitates or to viscosity changes hinding nutrient or drug absorption due to catheter obstruction (Izco et al., 2001). Furthermore, the grinding of solid oral medications or the administration of drugs with extreme $\mathrm{pH}$ values may cause mechanical problems as well as catheter obstruction (García de Tiedra, Alonso Herreros, 2004; Gámez Lechuga et al., 1998).

When the manipulation of pharmaceutical forms modifies the efficacy of the product and its tolerance by the patient it constitutes a pharmaceutical incompatibility. Also, some pharmaceutical forms, such as enteric coated tablets or controlled release tablets need special care when administered via catheters (Izco et al., 2001).

The decreased tolerance to nutritional support due to pharmacological action of the active principle or to any component of the formulation characterizes physiological incompatibility (Izco et al., 2001).

Pharmacological incompatibility occurs when the drug mechanism of action causes changes in EN tolerance or in the efficacy of other administered drugs (Izco et al., 2001).

Pharmacokinetic incompatibility occurs when the drug given via EFT causes changes in its pharmacokinetic properties such as bioavailability, distribution, metabolism and / or excretion (Izco et al., 2001).

It is therefore essential to perform proper selection and administration of the drug via this route to avoid the complications described, with the aim of ensuring the effectiveness of the drug and nutritional therapy in patients (Gámez Lechuga et al., 1998).

Numerous studies provide specific information and key recommendations for the correct administration of drugs via EFT. These works provide data on the peculiarities of the drugs that can be administered via this route and the alternatives to these drugs that should not be used.

The presence of a Multidisciplinary Team for Nutritional Therapy (MTNT) in hospitals can prevent and reduce complications and costs involved in this process, and ensure safety and efficacy in the treatment of patients (RDC n ${ }^{\circ}$ 63, 06/07/00) (Brasil, 2000; Moura, Reyes,
2002). The incorporation of a pharmacist in the MTNT is of fundamental importance to prevent problems related to administration of drugs via EFT. This professional plays an important role in correct selection and provision of information on drugs to be administered by this route, as well as in solving problems related to it $\left(\mathrm{RDC}^{\circ} 63,06 / 07 / 00\right)$ (Brasil, 2000; Gago Sánchez et al., 2006).

The aim of this study was to analyze the profile of the drug therapy administered through enteral feeding tube at the Medical Clinic of the Hospital dos Servidores do Estado (HSE) of Rio de Janeiro and to put forward proposals to improve care to patients with EFT.

\section{MATERIAL AND METHODS}

A retrospective study of medical prescriptions from the Medical Clinic of HSE sent to the Pharmacy Service between January and June 2007 was performed. Initially, the analysis was estimated for a period of one year but most data were not available for this period. The medical prescriptions sent to the Pharmacy Service were counted and those in which enteral nutrition (EN) via catheter was employed, were selected.

From the selected prescriptions, data was collected on the date of prescription, the distal placement of the EFT, the drugs prescribed via the EFT and the pharmaceutical form of each drug.

The dosage available for each drug in the Pharmacy Service during the study period was also considered. This information was available on AutoEst ${ }^{\circledR}$, an automated system (version 5.7).

The data were compiled into Microsoft EXCEL ${ }^{\circledR}$ spread sheet structured for this purpose. The information was processed to create secondary spread sheets in the same software to determine the profile of drug therapy via EFT using the following data: (1) total number of prescriptions for patients using EN; (2) number of patients in use of EN; (3) number of patients using drugs through EFT; (4) total number of prescriptions for patients using drugs via EFT; (5) time in use of EFT of patients during analysis; (6) distal placement of catheter in patients using EN; (7) average number of drugs per prescription to be administered by EFT; (8) drugs prescribed by catheter; (9) percentage of pharmaceutical forms of drugs prescribed by catheter, grouped by same active principle and pharmaceutical form, not taking into account their concentration; (10) total number of items found in prescriptions for drug administration via EFT; (11) frequency of drug items prescribed for administration via catheter.

The drugs prescribed via EFT were grouped accor- 
ding to their pharmacological group in the National List of Essential Drugs 2007 (Brasil, 2007), taking into consideration the same active principle and form, regardless of their concentration in the formulation.

A survey of drugs available in the institution in oral liquid form was conducted. This information identified the unfamiliarity of standardization of pharmaceutical forms of drugs available in the hospital among prescribers, as well as lack of awareness of professionals regarding the risks of modifying oral solid pharmaceutical forms.

After obtaining the relationship between drugs prescribed to patients by EFT, reference recommendations available on the use of these drugs through oral route were consulted. Careful evaluations of the use of drugs on analyzed prescriptions were performed according to the guidelines observed.

\section{RESULTS}

The Pharmacy Service of the HSE received 9975 prescriptions from the Medical Clinic between January and June, 2007. A total of 330 prescriptions were selected of 29 patients in use of EFT. The analysis of prescriptions showed that $26(89.6 \%)$ patients received medication via catheter, representing 319 prescriptions.

During the analysis period, 21 patients remained in use of EFT for up to 30 days, 5 patients for up to 60 days and 3 patients for a period greater than or equal to 90 days, at the Medical Clinic.

Among 29 patients studied at this period, 16 patients (55.1\%) had distal post-pyloric EFT placement and 13 patients $(44.9 \%)$ had distal stomach EFT placement.

Patients using drugs via EFT were found to be receiving an average of 4.1 drugs per prescription through this route.

Some drugs were prescribed in different doses and pharmaceutical forms. Figure 1 shows the distribution of pharmaceutical forms of drugs prescribed during the analyzed period.

On prescriptions of patients in use of drugs via EFT, 1,327 medicines were administered by this route. These drugs were grouped by pharmaceutical form, with captopril being the most prescribed, as shown in Table I.

The largest group of drugs prescribed to be administered through via catheter were the anti hypertensive agents $(30.9 \%)$, followed by anticonvulsants $(10.0 \%)$ and anti-ulcer drugs (7.0\%) (Figure 2). For this analysis, the antibacterial drugs, antifungal and the antiparasitic were considered Anti-Infective Agents, according to the classification of the National Essential Drugs List, 2007 (Brasil, 2007).

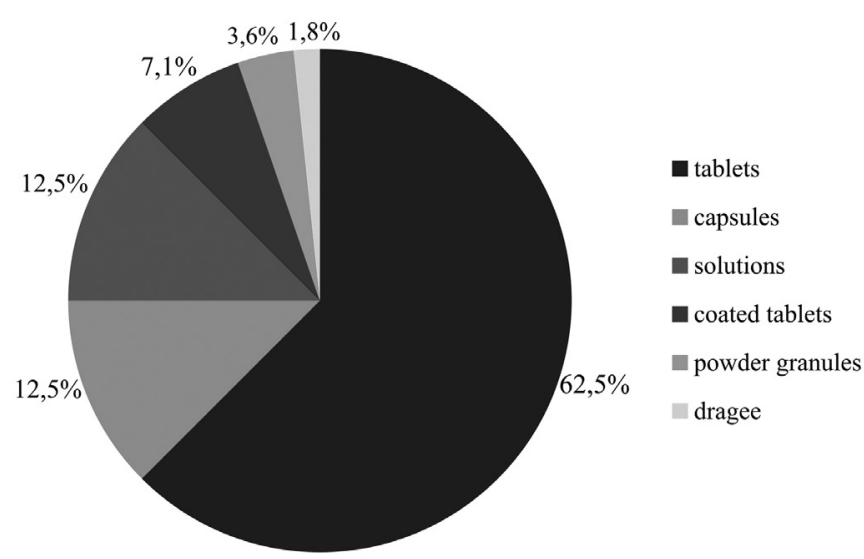

FIGURE 1 - Percentage of pharmaceutical forms of medicines prescribed by enteral feeding tubes between January and June, 2007 among the 26 patients analyzed at the Hospital dos Servidores do Estado in Rio de Janeiro.

Among 49 drugs prescribed in solid oral pharmaceutical forms, 17 (34.7\%) were also available on oral liquid form, implying that at least 290 prescriptions (21.8\%) could have reduced the risk of catheter obstruction.

The care taken in administration by EFT of the 56 drugs prescribed to the 26 patients was investigated based on the references used (Hidalgo et al., 1995; Gámez Lechuga et al., 1998; Izco et al., 2001; Beckwith et al., 2004; Garcia di Tiedra, Alonso Herreros, 2004; Alonso Herreros et al., 2004; Piñeiro Corrales, Olivera Fernández, Guindel Jiménez, 2006).

Analysis of prescription drugs regarding the distal placement of the EFT showed the prescription for one patient of haloperidol solution and one patient of $\mathrm{N}$-acetylcysteine powder with post-pyloric placement outside the guidelines found in the references consulted.

The same analysis was done on the administration of medicines by EFT with regard to the pharmaceutical forms available. Three patients were found using the nifedipine retard coated tablet, in disagreement with the reference recommendations (Hidalgo et al., 1995; Izco et al., 2001; López et al., 2003; Beckwith et al., 2004)

\section{DISCUSSION}

The use of medicines via EFT is commonly performed and of great relevance in clinical practice. The use of drugs by oral route is chosen due to its lower costs and iatrogenic effects (Gámez Lechuga et al., 1998), since it is more physiological and has fewer complications than the parenteral route (Izco et al., 2001).

In this study, a large number of prescriptions of drugs in their pharmaceutical solid oral form was noticed 
TABLE I - Frequency of medications prescribed for administration through enteral feeding tubes among the 26 patients assessed between January and June, 2007 at the Hospital dos Servidores do Estado (HSE) in Rio de Janeiro

\begin{tabular}{|c|c|c|c|c|c|c|c|}
\hline \multirow{2}{*}{ Drug } & \multirow{2}{*}{ PF } & \multicolumn{2}{|c|}{ Prescription } & \multirow{2}{*}{ Drug } & \multirow{2}{*}{$\mathrm{PF}$} & \multicolumn{2}{|c|}{ Prescription } \\
\hline & & $\mathrm{N}$ & $\%$ & & & $\mathrm{~N}$ & $\%$ \\
\hline Captopril & Tablet & 222 & 16.73 & Levothyroxine & Tablet & 15 & 1.13 \\
\hline Phenytoin & Tablet & 90 & 6.78 & Simvastatin & Tablet & 14 & 1.06 \\
\hline Ranitidine* & Tablet & 81 & 6.10 & Spironolactone & Tablet & 13 & 0.98 \\
\hline Bromopride* & Capsule & 76 & 5.73 & Amlodipine & Tablet & 12 & 0.90 \\
\hline Baclofen & Tablet & 68 & 5.12 & Omeprazole & Capsule & 12 & 0.90 \\
\hline Potassium chloride $6 \%$ & Solution & 49 & 3.69 & Nortriptyline & Capsule & 11 & 0.83 \\
\hline Ciprofloxacin & Tablet & 47 & 3.54 & Hydralazine & Dragee & 11 & 0.83 \\
\hline Hydrochlorothiazide & Tablet & 45 & 3.39 & Digoxin* & Tablet & 11 & 0.83 \\
\hline Atenolol & Tablet & 39 & 2.94 & Dipirone* & Tablet & 8 & 0.60 \\
\hline Acetylsalicylic acid & Tablet & 33 & 2.49 & Polystyrene sulfonate & $\begin{array}{l}\text { Powder } \\
\text { granule }\end{array}$ & 8 & 0.60 \\
\hline Fluoxetine* & Capsule & 30 & 2.26 & Thiabendazole* & Capsule & 7 & 0.53 \\
\hline Retard Nifedipine & Coated tablet & 30 & 2.26 & Metoclopramide* & Tablet & 7 & 0.53 \\
\hline Folic acid & Tablet & 28 & 2.11 & Vitamin B1 & Tablet & 7 & 0.53 \\
\hline Haloperidol & Solution & 28 & 2.11 & Tramadol & Capsule & 6 & 0.45 \\
\hline Carbamazepine* & Tablet & 26 & 1.96 & $\begin{array}{l}\text { Trimethoprim }+ \\
\text { sulfamethoxazole* }\end{array}$ & Tablet & 6 & 0.45 \\
\hline Sertraline & Tablet & 26 & 1.96 & Alopurinol & Tablet & 6 & 0.45 \\
\hline Prednisone & Tablet & 25 & 1.88 & Lactulose & Solution & 5 & 0.38 \\
\hline Diazepam & Tablet & 24 & 1.81 & Bromazepam & Tablet & 4 & 0.30 \\
\hline Dipirone & Solution & 23 & 1.73 & Fluconazole & Capsule & 4 & 0.30 \\
\hline Risperidone & Tablet & 20 & 1.51 & Morphine & Tablet & 3 & 0.23 \\
\hline Mineral Oil & Solution & 20 & 1.51 & Clonazepam* & Tablet & 1 & 0.08 \\
\hline Carvedilol & Tablet & 19 & 1.43 & Ferrous sulfate* & Coated tablet & 1 & 0.08 \\
\hline Furosemide & Tablet & 19 & 1.43 & Dexchlorpheniramine* & Tablet & 1 & 0.08 \\
\hline Metformin & Tablet & 19 & 1.43 & Albendazole* & Coated tablet & 1 & 0.08 \\
\hline Phenobarbital* & Tablet & 17 & 1.28 & Metronidazole* & Tablet & 1 & 0.08 \\
\hline Paracetamol & Solution & 15 & 1.13 & Norfloxacin & Tablet & 1 & 0.08 \\
\hline Clonazepam & Solution & 15 & 1.13 & Acetylcysteine & $\begin{array}{l}\text { Powder } \\
\text { granule }\end{array}$ & 1 & 0.08 \\
\hline Amoxicilin + Clavulanate* & Tablet & 15 & 1.13 & Vitamin B* & Coated tablet & 1 & 0.08 \\
\hline
\end{tabular}

PF: Pharmaceutical Form

*: Liquid oral pharmaceutical form available in the Pharmacy Service of the HSE

when equivalent liquid formulations were available. This suggests a possible lack of dosage forms of medicines available in the hospital to the prescribers, and also limited knowledge of professionals about the risks of the practice of modifying solid oral forms.

On the other hand, liquid formulations have problems and limitations inherent to their use related to the viscosity, osmolarity and the amount of sorbitol present in these formulations (Beckwith et al., 2004).

The administration of some oral liquids with high viscosity through the catheter could be hard or induce catheter obstruction, as occurs with the suspension of amoxicillin + clavulanate. These medications should be diluted in water to improve administration and prevent obstruction of the catheter (Gámez Lechuga et al., 1998; Garcia di Tiedra, Alonso Herreros, 2004). 


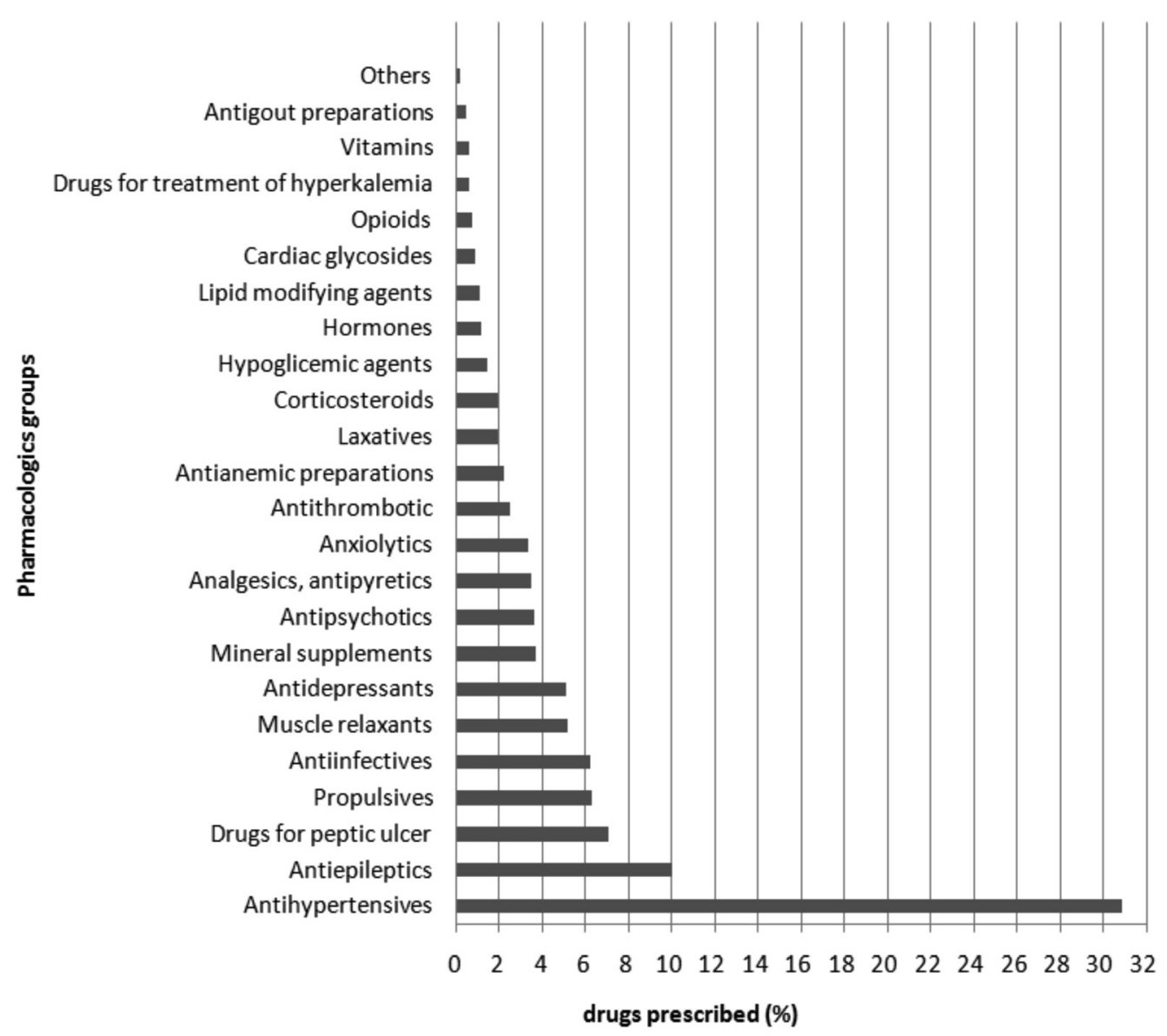

FIGURE 2 - Pharmacological group of drugs prescribed by enteral feeding tubes between January and June, 2007 among the 26 patients analyzed at the Hospital dos Servidores in Rio de Janeiro.

Other problem related to the administration of liquid forms through the EFT include high osmolarity which can cause gastrointestinal problems such as diarrhea, abdominal distension and vomiting. For instance, this can be observed upon administration of lactulose and the chloride potassium solutions of potassium chloride at $6 \%$. Dilution before administration is a way of reducing these effects (Beckwith et al., 2004).

The sorbitol present in liquid formulations is a frequent cause of abdominal distension and aerophagia with daily dose of $10 \mathrm{~g}$, while abdominal spasms and diarrhea can occur at a daily dose of $20 \mathrm{~g}$. The recommended change is to try the pharmaceutical form or to use alternative therapy available. The solution of paracetamol is an example of a product with a high amount of sorbitol in its formulation that was found in the prescriptions analyzed (Gámez Lechuga et al., 1998; Beckwith et al., 2004).

Among the oral pharmaceutical forms prescribed via EFT, solid forms were more commonly used. When prescribing medications in the form of tablets to patients using EFT, grinding and mixing in water is suggested to administer it as a suspension. The opening of capsules and preparing them as in the previous case is recommended. However, the suspensions prepared in this manner may be related with the obstruction of the EFT, representing a critical point of the process. An alternative to avoid this problem is the use of liquid formulations when they are available or parenteral preparations that can be administered orally, such as the tramadol (Hidalgo et al., 1995; Garcia di Tiedra, Alonso Herreros, 2004).

Moreover, the reduction of the pharmacological effect is observed through the grinding of pharmaceutical forms of enteric coated tablets due to the action of the gastric $\mathrm{pH}$ when the distal positioning of the catheter is in the stomach (Garcia di Tiedra, Alonso Herreros, 2004). In the analysis, two patients using omeprazole with gastric catheter were found. In this case, the correct procedure is to open the capsule and release the contents into a $5 \%$ glucose solution or in fruit juice with no grinding (Izco et al., 2001). Three patients using retard nifedipine were also found. The oral drugs in retard or controlled-release forms are contraindicated for open grinding or for administra- 
tion via catheter, as they can increase the speed of release of the active principle by increasing the absorption and plasma to toxic levels or to a lesser degree, lead to loss of the maintenance effect of plasma levels with time. In this case, liquid dosage forms should be chosen or options that do not have controlled-release, adapting for dose and dose range. (Hidalgo et al., 1995; Izco et al., 2001; López et al., 2003; Beckwith et al., 2004; Garcia di Tiedra, Alonso Herreros, 2004).

The administration of drugs with extreme values of $\mathrm{pH}(<3.5$ or $>10)$ together with EN may lead to precipitation of the drug and consequent obstruction of the catheter, it being indicated to interrupt EN $1 \mathrm{~h}$ before, and resume it $2 \mathrm{~h}$ after, drug administration. Also, cases must be considered where the distal placement of the catheter is post-pyloric and the middle $\mathrm{pH}$ is alkaline (duodenum and jejunum). In this case it is contraindicated to administer dosage forms with acidic $\mathrm{pH}$ that may lead to precipitation of the drug and consequent therapeutic failure (Gámez Lechuga et al., 1998; Izco et al., 2001; Garcia di Tiedra, Alonso Herreros, 2004). In the analysis, prescriptions drugs were found with $\mathrm{pH}<3.5$, such as metoclopramide tablet, fluoxetine capsule, haloperidol solution and nacetylcysteine powder. The use of haloperidol solution and $n$-acetylcysteine powder administered through a postpyloric catheter was observed in 2 patients.

When drug administration by EFT causes changes in pharmacokinetic properties such as bioavailability, distribution, metabolism and/or excretion or when I produces undesirable gastrointestinal effects, the procedure to be used is the interruption of nutrition $1 \mathrm{~h}$ before and $2 \mathrm{~h}$ after the administration of drugs such as atenolol, ciprofloxacin, digoxin, phenytoin, levothyroxine and norfloxacin. However, some drugs are more tolerable when administered concurrently with NE, such as acetylsalicylic acid, amoxicillin + clavulanate, amlodipine, carvedilol, dexchlorpheniramine, diazepam, furosemide and spironolactone (Izco et al., 2001).

According to the references studied, some oral solid medications that are not commercially available in liquid formulation, allows preparation through the development of an extemporaneous suspension. In these cases, the best alternative is the preparation of such formulations by the Department of Pharmacy of the institution and sending them in a ready form for administration. Among the drugs found, folic acid, allopurinol, baclofen, captopril, spironolactone, furosemide, hydrochlorothiazide and prednisone could benefit from this preparation (Hidalgo et al., 1995; Izco et al., 2001; Piñeiro Corrales, Olivera Fernández, Guindel Jiménez, 2006).

\section{FINAL CONSIDERATIONS}

The prescription of medicines via EFT is a procedure widely used in clinical practice. As can be observed in this study, the results showed that it is necessary for the health team involved in patient care to pay greater attention to ensure this practice is performed safely and effectively.

The administration of medications via catheter requires correct selection of the dosage form and the correct form of administration to ensure the effectiveness of pharmacotherapy, a reduction in adverse effects, prevention of catheter obstruction, and avoidance of problems related to possible complications that may cause nutritional failure.

The pharmacist, as part of the MTNT, has the responsibility to improve health through the safe and efficient use of medicines. Pharmaceutical intervention can be decisive in the detection and management of possible drugnutrient interactions in the prevention and identification of problems, by finding practical solutions, especially concerning guidelines for preparation and administration of medicines. The development of guides and manuals with guidelines for carrying out this practice, disclosure of the standard drugs at the institution available to prescribers, the inclusion of medicines with liquid formulations in the standardization and development of extemporaneous formulations designed for this purpose, also number among the actions of the pharmacist.

\section{ACKNOWLEDGMENTS}

The authors would like to thank employees of the pharmacy service of Hospital dos Servidores do Estado, and in particular the head for the support of this work.

\section{REFERENCES}

BECKWITH, M.C.; FEDDEMA, S.S.; BARTON, R.G.; GRAVES, C.A guide to drug therapy in patients with enteral feeding tubes: dosage form selection and administration methods. Hosp. Pharm., v.39, n.3, p.225-237, 2004.

BITENCOURT, F. Hospital dos Servidores do Estado - um patrimônio de saúde, arquitetura e história. Rio de Janeiro: OSCIP - Nova Sociedade, 2007. 136 p.

BRASIL. Ministério da Saúde. ANVISA - RDC n 63, de 06 de julho de 2000 - Aprova o Regulamento Técnico para fixar os requisitos mínimos exigidos para a Terapia de Nutrição Enteral. Diário Oficial da União, Brasília, DF, de 07 jul. 2000. Seção 1, p.82-99. 
BRASIL. Ministério da Saúde. Secretaria de Ciência, Tecnologia e Insumos Estratégicos. Departamento de Assistência Farmacêutica e Insumos Estratégicos. Relação Nacional de Medicamentos Essenciais: Rename. 4.ed. rev. Brasília: Editora do Ministério da Saúde, 2007. 286 p.

GÁMEZ LECHUGA, M.; CLOPÉS ESTELA, A.; CARDONA PERA, D.; FARRÉ RIBA, R.; CASTRO CELS, I.; BONAL DE FALGÁS, J. Importancia de las características físicoquímicas de los fármacos para su administración por sonda nasoentérica o enterostomía. Farm. Hosp., v.22, n.3, p.137143, 1998.

GARCÍA DE TIEDRA, M.; ALONSO HERREROS, J. M. Atención farmecéutica en pacientes portadores de sondas de nutrición enteral. Protocolo para la resolución de problemas relacionados con la administración de medicamentos, 2004. Available at: $<$ http://www.correofarmaceutico.com $>$. Accessed on: 22 jun. 2007.

HIDALGO, F.J.; DELGADO, E.; GARCÍA MARCO, D.; DE JUANA, P.; BERMEJO, T. Guía de administración de fármacos por sonda nasogástrica. Farm. Hosp., v.19, n.5, p.251-258, 1995.

IZCO, N.; CREUS, N.; MASSÓ, J.; CODINA, C.; RIBAS, J. Incompatibilidades fármaco-nutrición enteral: recomendaciones generales para su prevención. Farm. Hosp., v.25, n.1, p.13-24, 2001.
LÓPEZ, I.M.; PUIGVENTÓS, F.; MERCÉ, P.; BARROSO, M.A. Guía de administración de medicamentos por sonda nasogástrica. Hospital Universitario Son Dureta, 2003. Available at: $<$ http://www.elcomprimido.com $>$. Accessed on: 22 jun. 2007.

MOURA, M.R.L.; REYES, F.G.R.. Interação fármaco-nutriente: uma revisão. Rev. Nutr., v.15, n.2, p.223-238, 2002.

PIÑEIRO CORRALES, G.; OLIVERA FERNÁNDEZ, R.; GUINDEL JIMÉNEZ, C. Administración de medicamentos en pacientes con nutrición enteral mediante sonda. Nutr. Hosp., v.21, supl. 4, n. extra 4, p.139-197, 2006.

SOCIEDAD ESPAÑOLA DE NUTRICIÓN PARENTERAL Y ENTERAL. SENPE. Protocolos para la prescrición de nutrición parenteral y enteral, 1998. Available at: $<\mathrm{http}: / /$ www.senpe.com>. Accessed on: 14 mai. 2007.

WAITZBERG, D.L. Nutrição oral, enteral e parenteral na prática clínica. 3.ed. São Paulo: Editora Atheneu, 2000. $1858 \mathrm{p}$.

Received for publication on $09^{\text {th }}$ June 2010 Accepted for publication on $19^{\text {th }}$ December 2010 